\title{
Pramipexole and Tolcapone Alleviate Thermal and Mechanical Nociception in Naive Rats
}

\author{
Anita Mihaylova ${ }^{1}$, Ilia Kostadinov ${ }^{2}$, Nina Doncheva ${ }^{1}$, Delian Delev ${ }^{1}$, Hristina Zlatanova ${ }^{2}$ \\ ${ }^{1}$ Department of Pharmacology, Toxicology and Pharmacotherapy, Faculty of Pharmacy, Medical University of Plovdiv, Plovdiv, Bulgaria \\ ${ }^{2}$ Department of Pharmacology and Clinical Pharmacology, Faculty of Medicine, Medical University of Plovdiv, Plovdiv, Bulgaria \\ Corresponding author: Anita Mihaylova, Department of Pharmacology and Drug Toxicology, Faculty of Pharmacy, Medical University of Plovdiv, \\ 15A Vassil Aprilov Blvd., 4002 Plovdiv, Bulgaria; E-mail: animihailova@gmail.com; Tel.: +359 895707148
}

Received: 5 June 2020 Accepted: 15 June 2020 • Published: 30 June 2021

Citation: Mihaylova A, Kostadinov I, Doncheva N, Delev D, Zlatanova H. Pramipexole and tolcapone alleviate thermal and mechanical nociception in naive rats. Folia Med (Plovdiv) 2021;63(3):377-84. doi: 10.3897/folmed.63.e55136.

\begin{abstract}
Introduction: Parkinson's disease (PD) is a neurodegenerative disorder characterized mainly by its motor symptoms. The non-motor symptoms including pain are increasingly recognized in the last few decades. Existing evidence suggests that the dopaminergic neurotransmission has an essential role in pain control.
\end{abstract}

Aim: The aim of the present study was to investigate the antinociceptive effect of dopaminergic drugs pramipexole and tolcapone against chemical and thermal stimuli in naive rats.

Materials and methods: Male Wistar rats divided into 8 groups $(\mathrm{n}=8$ ): saline; diclofenac $25 \mathrm{mg} / \mathrm{kg}$ body weight (bw) (positive control); pramipexole $0.5 ; 1$ and $3 \mathrm{mg} / \mathrm{kg}$ bw; tolacapone $5 ; 15$ and $30 \mathrm{mg} / \mathrm{kg}$ bw. Paw pressure and plantar tests were performed. Paw withdrawal pressure and latent time were measured. Statistical analysis was done by SPSS 19.

Results: In the paw pressure test, pramipexole, in a dose of 1 and $3 \mathrm{mg} / \mathrm{kg}$ bw and tolcapone in a dose of $30 \mathrm{mg} / \mathrm{kg}$ bw, increased significantly the latency at 1,2 , and 3 hours compared to saline $(p<0.05)$. In the plantar test, only the highest dose of pramipexole reached significance at 3 hours compared to the control rats $(p<0.05)$. In contrast to pramipexole the three experimental groups with tolcapone markedly increased the latent time at 1 and 3 hours compared to saline $(p<0.05)$.

Conclusions: Pramipexole and tolcapone reduce mechanical and thermal nociception in naïve rats by enhancing dopaminergic neurotransmission at both spinal and supraspinal levels. In addition, tolcapone stimulates noradrenergic mediation which may contribute to its antinociceptive effect.

\section{Keywords}

dopamine, pain, pramipexole, tolcapone

\section{INTRODUCTION}

Parkinson's disease (PD) is a neurodegenerative disorder that affects about $1 \%$ of the population over the age of $65 .{ }^{1}$ $\mathrm{PD}$ is caused by loss of dopaminergic neurons in substantia nigra and strial dopamine depletion and is generally charac- terized by its motor symptoms (MS): bradykinesia, rigidity, and postural tremor. ${ }^{2}$ However, the non-motor symptoms (NMS) of PD such as pain, cognitive decline, autonomic, and sensory dysfunction have become increasingly recognized in the last few decades. Approximately half of the PD patients complain of pain whose intensity varies from mild 
to intractable. ${ }^{3}$ It can occur at any time during the disease and even can precede the motor symptoms. ${ }^{4}$ Recent studies have demonstrated that NMS and pain in particular have a greater impact on quality of life than MS and they may further expand the burden of patient's illness. ${ }^{5}$

The origin of pain in PD remains obscure. The monoaminergic system is important for pain modulation. While the role of norepinephrine and serotonin in pain inhibition is well established the engagement of dopamine in pain modulation is less studied. ${ }^{6}$ Existing clinical and preclinical evidence suggests that the dopaminergic neurotransmission has an essential role in pain processing and perception at spinal and supraspinal regions, such as basal ganglia, anterior cingulate cortex, insula, thalamus, etc. ${ }^{7}$ Stimulation of $\mathrm{D}_{2}$-like dopamine receptors inhibits nociceptive responses although $\mathrm{D}_{1}$-like receptors may also contribute to the antinociceptive effect of dopamine. Disruption in dopamine signalling may modulate pain processing directly by amplifying or reducing the nociceptive signal propagation and indirectly by affecting mood and cognition which are involved in pain signals interpretation. ${ }^{8}$ Decreased dopamine levels are likely to take part in the painful symptoms experienced by patients with PD. ${ }^{9}$

The role of dopamine in pain modulation suggests that drug-enhancing dopaminergic mediation may be useful in the treatment of pain in PD and other disorders. This boosts the motivation for further investigation involving animal models, which may lead to the development of novel therapeutic approaches to pain treatment. Bupropion (antidepressant that inhibits both noradrenaline and dopamine reuptake) has antihyperalgesic action in an animal model of neuropathic pain and the effect is reduced in the presence of the $\mathrm{D}_{2}$ receptor antagonist sulpiride. ${ }^{10}$ Dopamine replacement therapy with levodopa increases pain threshold in parkinsonian patients. ${ }^{11}$ The dopamine agonist apomorphine increases the cold-pain threshold in a condition different from PD (chronic radicular pain). ${ }^{12}$ Pramipexole is $\mathrm{D}_{2} / \mathrm{D}_{3}$ dopamine receptor agonist found to inhibit thermal hypersensitivity in rats with 6-hydroxydopamine (6-OHDA) model of PD. ${ }^{13}$ Clinical trials demonstrated that this drug decreases pain in patients with fibromyalgia. ${ }^{14}$ Tolcapone is an inhibitor of dopamine metabolising enzyme catechol-O-methyltransferase (COMT). Since low COMT activity is associated with high dopamine levels, we can suggest that tolcapone might have pain-relieving properties although the available data are controversial.

\section{AIM}

The analgesic action of dopaminergic drugs is revealed mainly in experimental models of PD. Since increasing evidence shows that these agents might augment the pain treatment in non-parkinsonian patients, the aim of our study was to investigate the antinociceptive effect of the dopaminergic agents pramipexole (PMX) and tolcapone (TCP) against chemical and thermal stimuli in naïve rats.

\section{MATERIALS AND METHODS}

\section{Ethical statement}

All experimental procedures were carried out in accordance with the European Convention for the Protection of Vertebrate Animals used for Experimental and other Scientific Purposes. For the present study, permission was obtained from the Ethics Committee at the Medical University of Plovdiv, No 2/19.04.2018 and Animal Health and Welfare Directorate of the Bulgarian Food Safety Agency permit No 4/09.12.2015.

The following drugs were used: pramipexole (SigmaAldrich), tolcapone (Sigma-Aldrich), diclofenac (Sandoz).

\section{Animals}

Male albino Wistar rats (200 $\pm 20 \mathrm{~g}$ body weight $)$ were used. They were kept in standard cages under controlled laboratory conditions (08:00-20:00 light-dark cycle, temperature $22 \pm 1^{\circ} \mathrm{C}$, and humidity $55 \pm 5 \%$ ) with ad libitum access to food and water. Efforts were made to reduce the number of animals used and to lessen their suffering.

To evaluate the antinociceptive properties of PMX and TCP, the rats were divided randomly into 8 groups $(n=8)$ as follows: group 1 (control): saline $0.1 \mathrm{ml} / 100 \mathrm{~g}$ body weight; group 2 (positive control): diclofenac ( $25 \mathrm{mg} / \mathrm{kg} \mathrm{bw})$; group 3: pramipexole $(0.5 \mathrm{mg} / \mathrm{kg} \mathrm{bw})$; group 4: pramipexole (1 mg/kg bw); group 5: pramipexole (3 mg/kg bw); group 6: tolcapone ( $5 \mathrm{mg} / \mathrm{kg} \mathrm{bw})$; group 7: tolcapone (15 mg/kg bw); group 8: tolcapone $(30 \mathrm{mg} / \mathrm{kg} \mathrm{bw})$.

All animals were pre-treated with PMX and TCP for 7 days. The drugs were dissolved in saline and administered by oral lavage.

\section{Nociceptive tests}

\section{Nociceptive paw pressure test (Randall- Selitto test; analgesiometer)}

Paw pressure threshold was measured by analgesiometer apparatus (Ugo Basile, Italy). Randall-Selitto (RS) test quantifies withdrawal responses evoked by application of a linearly increasing mechanical pressure to the rats' hind paw. The pressure was applied on the dorsum of the right hind paw. The intensity of pressure was gradually increased in steps of 10 grams. End point was reached upon hind paw withdrawal. Cut-off was set at $250 \mathrm{~g}$ to avoid tissue damage. The assay was performed at 1,2 , and 3 hours $(60,120$, and 180 minutes) after drug administration. Basal latency was measured before treatment and animals with deviation in the response were excluded.

\section{Plantar test (Hargreaves' method)}

Plantar test apparatus (Ugo Basile, Italy) was used to evaluate the nociceptive thresholds to thermal stimuli. The 
animals were placed in a see-through plastic chamber and allowed to accustom for 5 min before testing. A small cylinder with infrared emitter was placed under the transparent floor of the chamber. The beam diameter was around $12 \mathrm{~mm}$. In addition, the cylinder had an infrared sensor which ceased the emission when animal moved its hind paw, therefore recording latency and stopping the heat. The test was repeated three times at 1,2, and 3 hours $(60,120$, and 180 minutes) following drug administration. The latent time taken for the animal to withdraw its paw was measured. To prevent tissue damage cut-off time was set up in 30 seconds.

\section{Statistical analysis}

Statistical analysis was performed using IBM SPSS Statistics 19.0. All data were expressed as mean \pm SEM. Data were analysed by one-way ANOVA, followed by Tukey's post hoc test for comparisons between the groups. A value of $p<0.05$ was considered statistically significant.

\section{RESULTS}

\section{Effects of pramipexole and tolcapone in nociceptive paw pressure test}

In Randall-Selitto test, the pressure at which the animals treated with diclofenac ( $25 \mathrm{mg} / \mathrm{kg} \mathrm{bw}$ ) withdrew their hind paw was $18 \pm 1 \mathrm{~g}$ which was significantly higher compared to the control group at 60,120 , and 180 minutes $(p<0.0001)$
(Figs 1, 2). The three experimental groups with PMX at doses of $0.5,1$, and $3 \mathrm{mg} / \mathrm{kg}$ bw markedly increased that index during the first two hours when compared to saline $(p<0.05, p<0.001$, and $p<0.05$, respectively at 1 hour, and $p<0.001, p<0.01$, and $p<0.001$, respectively at 2 hours) whereas at 3 hours, rats treated with PMX at a dose of 1 and 3 $\mathrm{mg} / \mathrm{kg}$ bw showed significant increase in comparison to the vehicle animals $(p<0.001$ and $p<0.01$, respectively) (Fig. 1).

Our investigation on tolcapone showed that TCP at doses of 15 and $30 \mathrm{mg} / \mathrm{kg}$ bw significantly increased the pressure for paw withdraw at 60 minutes compared to the rats treated with saline $(p<0.05)$. At 2 hours, only the highest dose of TCP notably increased that index $(p<0.001)$ while at 3 hours, the three experimental groups reached significance in comparison to the saline group $(p<0.0001, p<0.01$, and $p<0.0001$, respectively) (Fig. 2).

The effect of tolcapone on nociceptive threshold was greater than that of pramipexole. At 3 hours, significance was reached when comparing the highest doses of TCP and PMX $(p<0.05)$ (Table 1).

\section{Effects of pramipexole and tolcapone on pain threshold in plantar test}

Rats treated with diclofenac (25 mg/kg bw) significantly increased the time for reaction at 60,120 , and 180 minutes when compared to the vehicle group $(p<0.001)$ (Figs 3, 4). The group treated with the highest dose of PMX (3 mg/kg bw) reached significance at 3 hours compared to the control rats $(p<0.001)$ (Fig. 3).

In contrast to PMX, all experimental groups treated with TCP markedly increased the latent time at 60 and 180

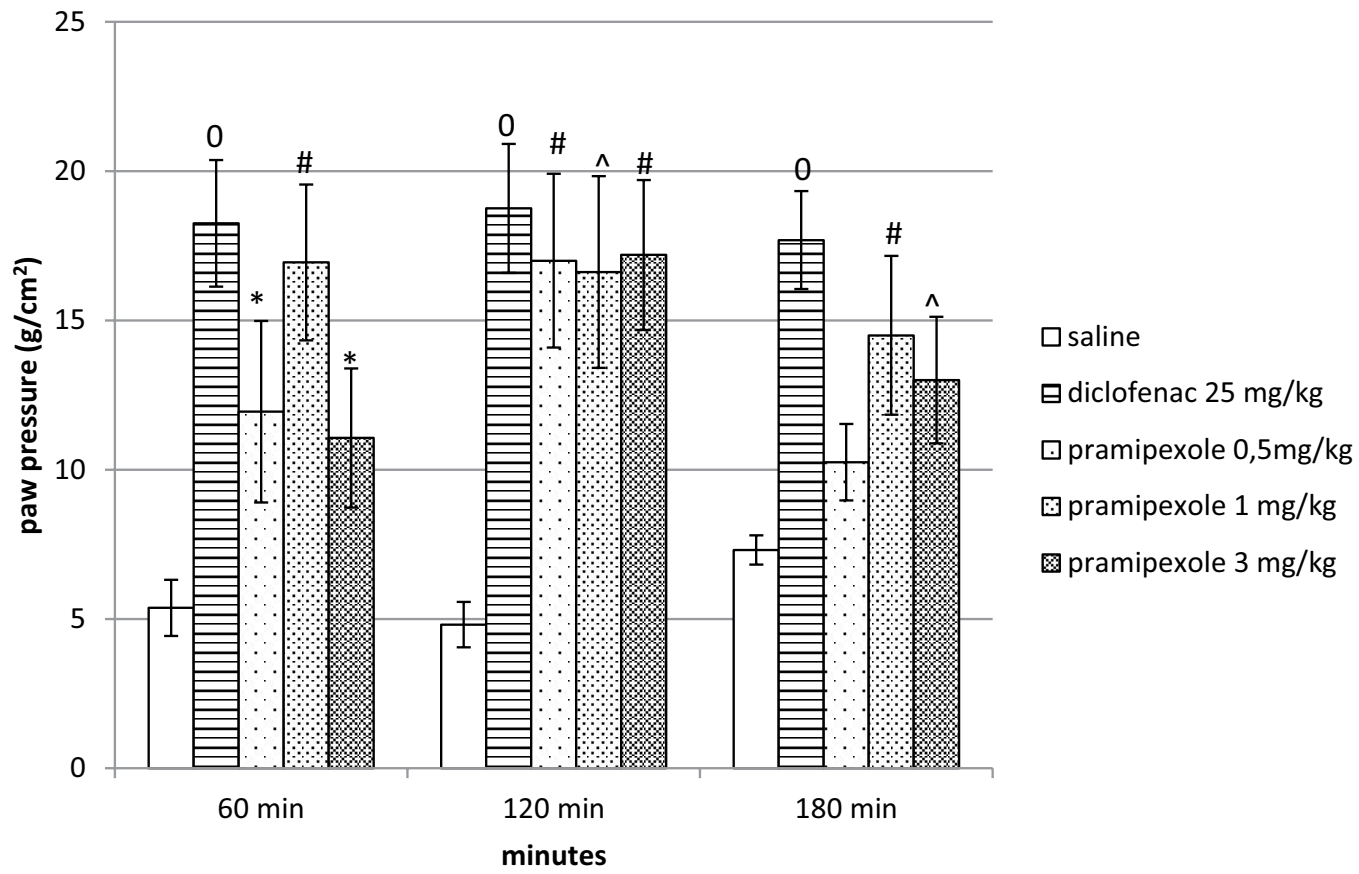

Figure 1. Effects of pramipexole on the nociceptive threshold in paw pressure test (Randall-Selitto test). ${ }^{*} p<0.05$ vs. the saline control group; $\wedge^{\wedge}<0.01$ vs. the saline control group; ${ }^{\#} p<0.001$ vs. the saline control group; ${ }^{0} p<0.0001$ vs. the saline control group. 


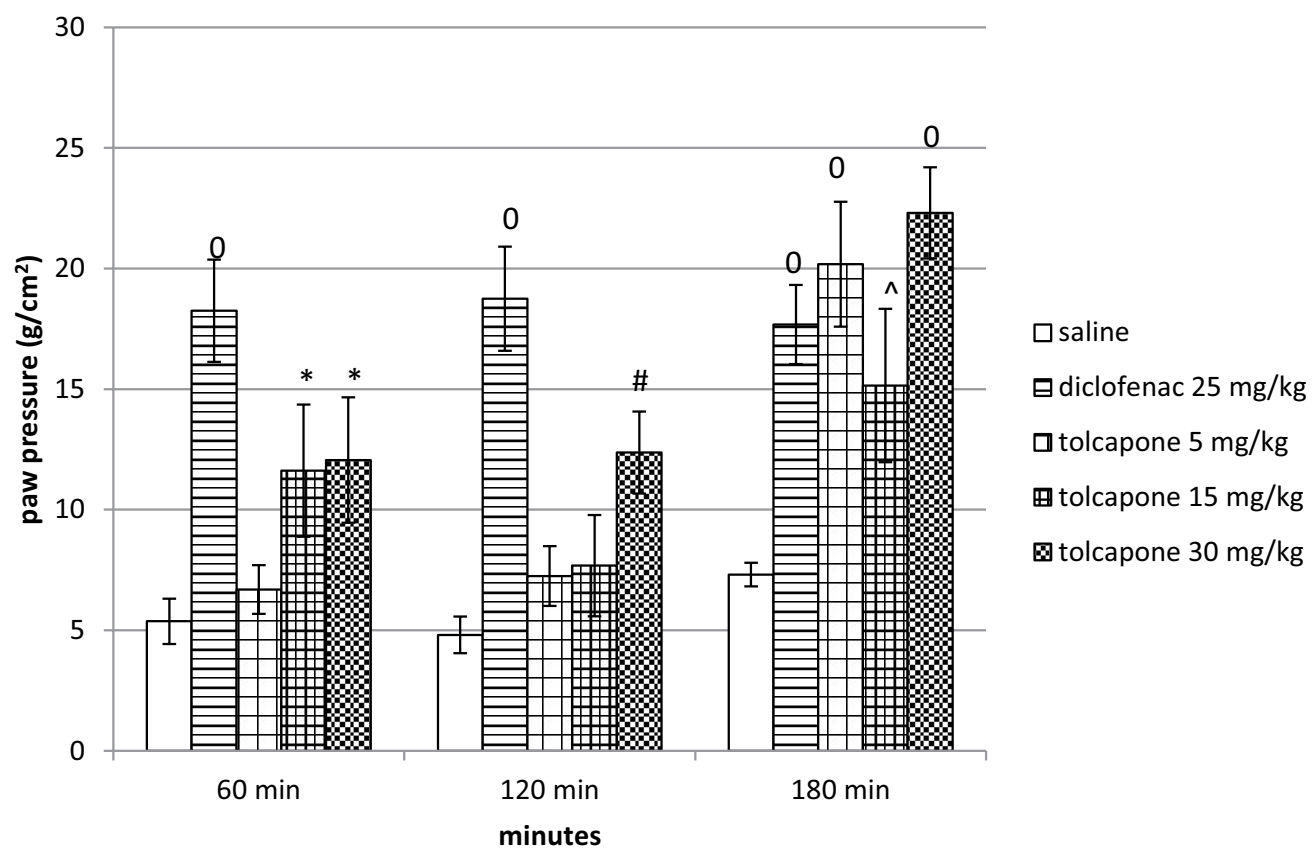

Figure 2. Effects of tolcapone on the nociceptive threshold in paw pressure test (Randall-Selitto test). ${ }^{\star} p<0.05$ vs. the saline control group; $\wedge p<0.01$ vs. the saline control group; ${ }^{\sharp} p<0.001$ vs. the saline control group; ${ }^{0} p<0.0001$ vs. the saline control group.

Table 1. Comparison of the effects of pramipexole and tolcapone on the nociceptive threshold in paw pressure test

\begin{tabular}{llll}
\hline Group & $\begin{array}{l}\text { 1 hour } \\
\text { mean } \pm \text { SD }\end{array}$ & $\begin{array}{l}\text { 2 hours } \\
\text { mean } \pm \text { SD }\end{array}$ & $\begin{array}{l}\text { 3 hours } \\
\text { mean } \pm \text { SD }\end{array}$ \\
\hline PMX $1 \mathrm{mg} / \mathrm{kg} \mathrm{bw}$ & $16.937 \pm 2.615$ & $16.625 \pm 3.206$ & $14.500 \pm 2.664$ \\
PMX $3 \mathrm{mg} / \mathrm{kg} \mathrm{bw}$ & $11.062 \pm 2.326$ & $17.187 \pm 2.508$ & $13.000 \pm 2.121$ \\
TCP $15 \mathrm{mg} / \mathrm{kg} \mathrm{bw}$ & $11.625 \pm 2.736$ & $7.687 \pm 2.104$ & $15.150 \pm 3.180$ \\
TCP $30 \mathrm{mg} / \mathrm{kg} \mathrm{bw}$ & $12.062 \pm 2.602$ & $12.375 \pm 1.700$ & $22.312 \pm 1.896^{*}$ \\
\hline
\end{tabular}

${ }^{*} p<0.05$ when compared to PMX $3 \mathrm{mg} / \mathrm{kg}$ bw.

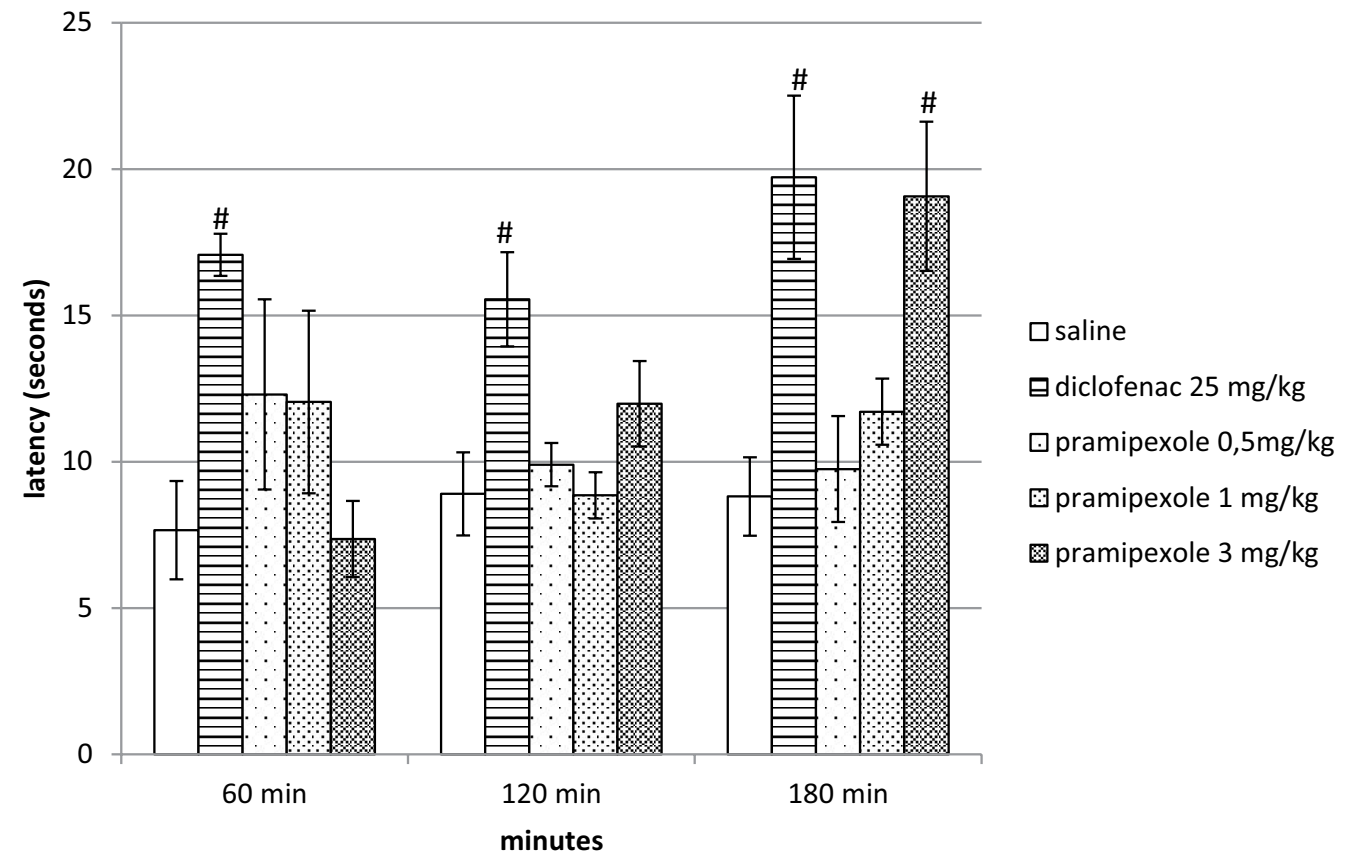

Figure 3. Effects of pramipexole on pain threshold in plantar test (Hargreave's method) in rats. ${ }^{\#} p<0.001$ vs. the saline control group. 


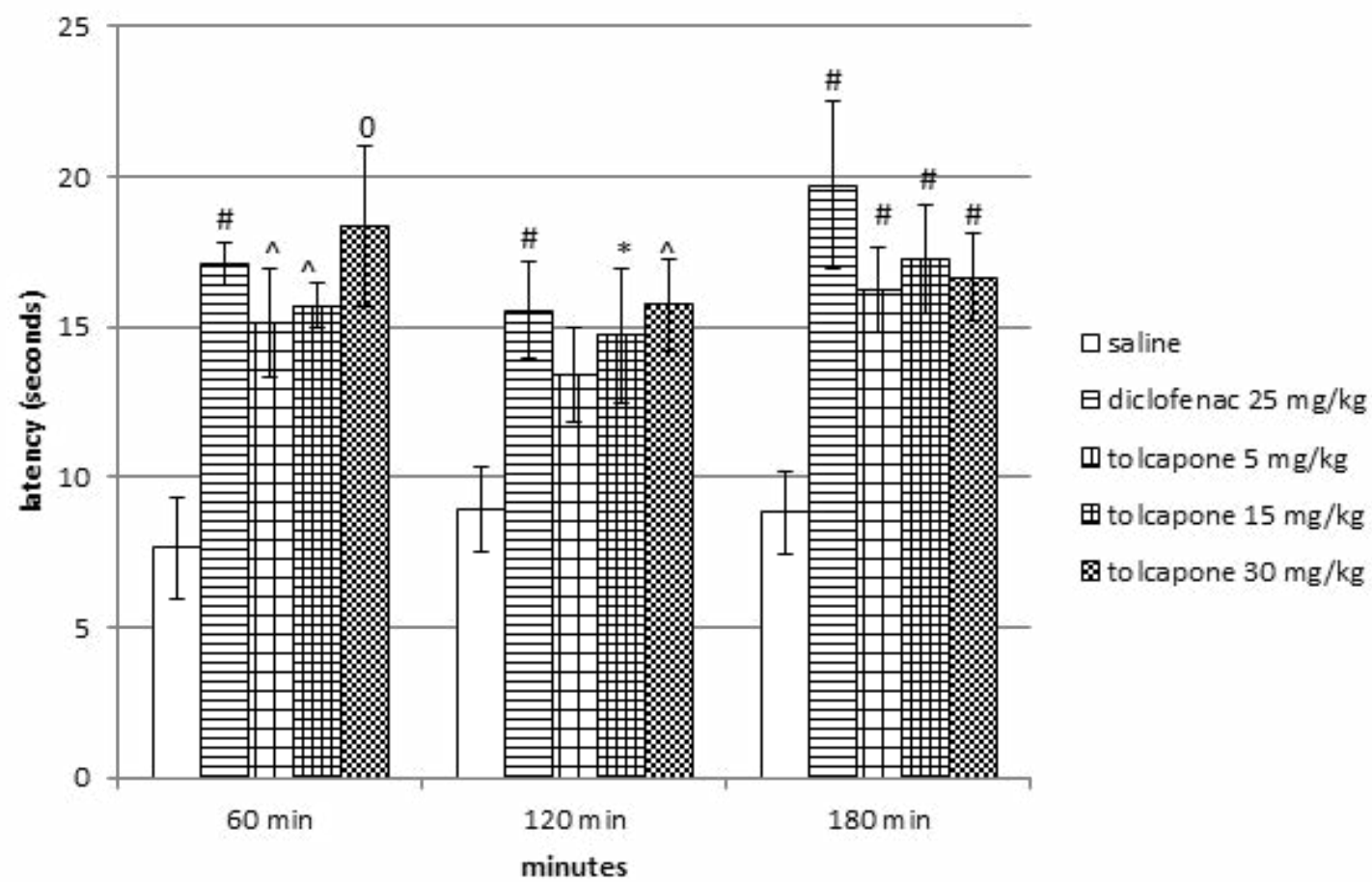

Figure 4. Effect of tolcapone on pain threshold in plantar test (Hargreave's method) in rats. ${ }^{*} p<0.05$ vs. the saline control group; ${ }^{\wedge} p<0.01$ vs. the saline control group; ${ }^{\#} p<0.001$ vs. the saline control group; ${ }^{0} p<0.0001$ vs. the saline control group.

minutes compared to saline $(p<0.01, p<0.01$, and $p<0.0001$, respectively, at 1 hour and $p<0.001$ at 3 hours). At 120 minutes, only the two doses of TCP (15 and $30 \mathrm{mg} / \mathrm{kg} \mathrm{bw})$ climbed up to a significant increase of latency $(p<0.05$ and $p<0.01$, respectively) whereas the lowest dose prolonged the time for reaction insignificantly (Fig. 4).

\section{DISCUSSION}

The major finding of our study is that systemic administration of dopaminergic drugs inhibits mechanical and thermal nociceptive response in naïve rats. The results from our experiments are aligned with previous preclinical research which demonstrated that dopamine receptor agonists attenuate nociception. Taylor and colleagues found that bilateral microinjection of the $\mathrm{D}_{2}$-like receptor agonist quinpirole in nucleus accumbens inhibits persistent nociception in the formalin test in rats. ${ }^{15}$ In experimental conditions the analgesic effect of pramipexole is demonstrated in animals with artificially-induced $\mathrm{PD}^{13,16}$ but not in naïve rats. Cao $\mathrm{LF}$ et al. found that pramipexole reduces thermal, but not mechanical pain hypersensitivity in rats with 6-OHD-induced model of PD. ${ }^{13}$ Our results showed that in naïve rats, pramipexole inhibits both types of nociception. Pain reducing properties of dopamine receptor agonists in non-parkinsonian patients are demonstrated in clinical trials. ${ }^{12,14}$ COMT inhibitors are known to increase sensitivity to nociceptive stimuli although there are some controversial data. ${ }^{17}$ Nitecapone has antiallodynic effect in neuropathic pain and another COMT inhibitor, OR 486, demonstrated that low COMT activity results in decreased nociceptive activity of the dorsal horn and reduced expression of spinal longterm potentiation after noxious inputs. ${ }^{18}$

The role of the dopaminergic system in the regulation of motor functions, reward processes, attention and motivation is well established. ${ }^{19}$ The idea about the pain-relieving properties of dopaminergic drugs comes from the fact that dopamine also plays an important role in the modulation of nociceptive transmission. Five subtypes of dopamine receptors have been distinguished. Based on their pharmacology and functional properties they can be divided into $\mathrm{D}_{1}$-like $\left(\mathrm{D}_{1}, \mathrm{D}_{5}\right)$ and $\mathrm{D}_{2}$-like $\left(\mathrm{D}_{2}, \mathrm{D}_{3}, \mathrm{D}_{4}\right)$ dopamine receptors. $\mathrm{D}_{1}$ and $\mathrm{D}_{2}$ receptors are mainly involved in the modulation of pain but have opposing functions. Stimulation of $D_{2}$ receptors has an antinociceptive effect, whereas $D_{1}$ receptors are more likely to have pro-nociceptive properties. ${ }^{6}$

Pramipexole is a dopamine receptor agonist used in the treatment of $\mathrm{PD}$. It has high affinity for $\mathrm{D}_{2} / \mathrm{D}_{3}$ receptor subtypes and no affinity for $D_{1} / D_{5}$ receptors. ${ }^{20}$ Dopamine can modulate the nociceptive transmission at spinal and supraspinal levels, including the basal ganglia, cerebral cortex and periaqueductal gray. ${ }^{7,21}$ The plantar test is a modification of the hot plate test and provides more localized thermal stimulus on an unrestrained animal. This minimizes the role of the subjective factor during the experiments. Behavioural response is more complex than that in the paw pressure test and involves supraspinal structures. ${ }^{22}$ Dorso-lateral striatum is involved not only in the regulation of motor functions bit also in the supraspinal pain modulation. Striatal micro-injection of the non-selective dopamine receptor antagonist haloperidol and the selective $\mathrm{D}_{2}$ 
receptor antagonist eticlopride enhances the nociceptive response in the formalin test in rats whereas the injection of the non-selective dopamine agonist apomorphine and the $\mathrm{D}_{2}$ agonist quinpirole produce antinociceptive effect. ${ }^{23}$ Cortical structures are also implicated in the dopamine-dependent modulation of pain transmission. Sheng $\mathrm{HY}$ et al. showed that activation of $\mathrm{D}_{2}$ receptors in the ventrolateral orbital cortex has an antinociceptive effect. ${ }^{24}$ The density of $\mathrm{D}_{2} / \mathrm{D}_{3}$ receptors in the brain is increased in patients with painful conditions. ${ }^{21}$ Based on our results and aforementioned data about the role of dopamine and its receptors in the control of pain we can speculate that pramipexole exerts its antinociceptive effect through stimulation of supraspinal $\mathrm{D}_{2}$-like receptors.

Tolcapone inhibits COMT enzyme and slows down catabolism of extracellular dopamine. In the striatum, the reuptake of dopamine by a dopamine transporter is more important for termination of its action. Although COMT plays a more significant role in regulating dopamine levels in the prefrontal cortex, the rate of dopamine catabolism in this brain structure affects dopamine amount in the striatum. Low COMT activity results in high levels of tonic dopamine and decreased phasic dopamine release in the striatum. ${ }^{8}$ Striatal dopaminergic system is associated with inter-individual differences in sensory and affective aspects of pain. ${ }^{25}$ Tolcapone, by inhibiting COMT enzyme, probably increases striatal tonic dopamine levels and increases pain threshold. Unlike pramipexole, which is a $\mathrm{D}_{2} /{ }_{3}$ receptor agonist, tolcapone elevates dopamine levels which in turn stimulate all type of dopamine receptors. This could lead to pro-nociceptive action due to stimulation of $D_{1} / 5$ receptors which is not observed in our study. Flores J et al. showed that $\mathrm{D}_{1}$ receptors in the periaqueductal gray matter enhance opioid-induced analgesia and this receptor type participates in supraspinal antinociceptive effect of dopamine. ${ }^{26}$ Moreover, tolcapone also protects noradrenalin from degradation by COMT and noradrenergic neurotransmission has a proven paininhibiting function.

Behavioural responses in the paw pressure test are mediated through spinal nociceptive mechanisms. ${ }^{27}$ Based on our results, we can assume that spinal dopaminergic system plays an essential role in the observed analgesic effect of pramipexole and tolcapone. Activation of $\mathrm{D}_{2}$ receptors after intratecal administration of quinpirole, a $\mathrm{D}_{2}$-like agonist, produces analgesia under the conditions of mechanical nociception. ${ }^{28}$ This supports the hypothesis about the role of $\mathrm{D}_{2}$ receptors in the observed effect. In the mammalian spinal cord the major source of dopamine are dopaminergic fibers from the A 11 region of the dorsoposterior hypothalamus. All dopamine receptors are found in the spinal cord, but $\mathrm{D}_{2}$ type predominates and has an important role for the postsynaptic dopaminergic actions. ${ }^{29}$ Dopamine receptors are found not only in the spinal cord but also in the dorsal root ganglia. Dopamine modulates presynaptic transient receptor potential vanilloid type 1 receptor in the latter through activation of $D_{1} / D_{5}$ receptors. In this way presynaptic dopamine receptors inhibit the transmission of nociceptive impulses between primary nociceptors and neurons of the dorsal horn of the spinal cord. ${ }^{30} \mathrm{Lu} \mathrm{Y}$ et al. demonstrated that dopamine exerted presynaptic inhibition of the pain signalling from primary $\mathrm{A} \delta$ - and $\mathrm{C}$ fiber nociceptors to lamina I projection neurons. $\mathrm{D}_{3}$ and $\mathrm{D}_{4}$ receptors also contribute to the antinociceptive effect of dopamine in the spinal cord. ${ }^{31}$ This could explain the more prominent effect of tolcapone on mechanical hyperalgesia than that of pramipexole. The effect of the COMT inhibitor was registered at all doses and with the highest dose, it was greater than that of diclofenac although the difference did not reach statistical significance. Tolcapone inhibits dopamine metabolism and increases dopamine which in turn acts at all types of dopamine receptors attaining pre- and postsynaptic inhibition on pain transmission.

Another possible explanation for the analgesic effect of tolcapone, in both the mechanical and thermal nociception, is the enhancement of the noradrenergic neurotransmission. COMT is involved not only in the degradation of dopamine, but also in that of noradrenaline. It has a well-known role in the inhibition of pain at the spinal and supraspinal levels. The major source of spinal cord noradrenaline is locus coeruleus (LC), but this brain structure has projections to the basal ganglia, hippocampus, prefrontal cortex, somatosensory cortex, etc. ${ }^{32}$ The noradrenergic system is mainly implicated in the descending pain control, influencing the spinal transmission of nociceptive stimuli. ${ }^{33}$ $\mathrm{PD}$ is defined by a massive loss of nigrostriatal dopamine neurons, but noradrenergic neurotransmission is also affected. Postmortem examinations showed that degeneration of LC is common in parkinsonian patients and is characterized with loss of neurons, presence of Lewy bodies or both. ${ }^{34}$ The role of noradrenaline deficiency in the development of hyperalgesia in PD is not well established. Experimental data showed that in rats with 6-hydroxydopamineinduced model of PD restoration of noradrenergic inhibitory tone with the pharmacologically inactive noradrenaline precursor droxidopa, a2-adrenoreceptor agonist clonidine and duloxetine (noradrenaline and serotonin reuptake inhibitor) reduces pain hypersensitivity. ${ }^{13}$ Tolcapone probably increases noradrenaline levels in the spinal cord which in turn causes antinociception. The latter is mainly due to stimulation of $a 2$-adrenoreceptor ${ }^{6}$, but a1-adrenoceptors activate inhibitory GABAergic interneurons which may contribute to the analgesic effect of noradrenaline. ${ }^{35}$ Further investigations are needed to reveal the mechanism of tolcapone-induced antinociception.

\section{CONCLUSIONS}

Pramipexole and tolcapone reduce mechanical and thermal nociception in naïve rats by enhancing dopaminergic neurotransmission at both spinal and supraspinal levels. In addition, tolcapone stimulates noradrenergic mediation which may contribute to its antinociceptive effect. 


\section{Competing interests}

The authors have declared that no competing interests exist.

\section{REFERENCES}

1. Phani S, Loike JD, Przedborski S. Neurodegeneration and inflammation in Parkinson's disease. Parkinsonism Relat Disord 2012; 18(1):207-9.

2. Tysnes O, Storstein A. Epidemiology of Parkinson's disease. J Neural Transm 2017; 124:901-5.

3. Hanagasi HA, Akat $\mathrm{S}$, Gurvit $\mathrm{H}$, et al. Pain is common in Parkinson's disease. Clin Neurol Neurosurg 2011; 113(1):11-3.

4. Ha AD, Jankovic J. Pain in Parkinson's disease. Mov Disord 2012; 27(4):485-91.

5. Pfeiffer RF. Non-motor symptoms in Parkinson's disease. Parkinsonism Relat Disord 2016; 22(1):119-22.

6. Bravo L, Llorca-Torralba $\mathrm{M}$, Berrocoso E, et al. Monoamines as drug targets in chronic pain: focusing on neuropathic pain. Front Neurosci 2019; 13:1268.

7. Wood PB. Role of central dopamine in pain and analgesia. Expert Rev Neurother 2008; 8(5):781-97.

8. Jarcho JM, Mayer EA, Jiang ZK, et al. Pain, affective symptoms, and cognitive deficits in patients with cerebral dopamine dysfunction. PAIN 2012; 153(4):744-54.

9. Blanchet PJ, Brefel-Courbon C. Chronic pain and pain processing in Parkinson's disease. Prog Neuropsychopharmacol Biol Psychiatry 2018; 87(Pt B):200-6.

10. Hoshino $\mathrm{H}$, Obata $\mathrm{H}$, Nakajima $\mathrm{K}$, et al. The antihyperalgesic effects of intrathecal bupropion, a dopamine and noradrenaline reuptake inhibitor, in a rat model of neuropathic pain. Anesth Analg 2015; 120(2):460-6.

11. Cury RG, Galhardoni R, Fonoff ET, et al. Sensory abnormalities and pain in Parkinson disease and its modulation by treatment of motor symptoms. Eur J Pain 2016; 20:151-65.

12. Haddad M, Pud D, Treister R, et al. The effects of a dopamine agonist (apomorphine) on experimental and spontaneous pain in patients with chronic radicular pain: A randomized, double-blind, placebocontrolled, cross-over study. PLoS One 2018; 13(4):e0195287.

13. Cao LF, Peng XY, Huang Y, et al. Restoring spinal noradrenergic inhibitory tone attenuates pain hypersensitivity in a rat model of Parkinson's disease. Neural Plast 2016; 2016:6383240.

14. Holman AJ, Myers RR. A randomized, double-blind, placebo-controlled trial of pramipexole, a dopamine agonist, in patients with fibromyalgia receiving concomitant medications. Arthritis Rheum 2005; 52(8):2495-505.

15. Taylor BK, Joshi C, Uppal H. Stimulation of dopamine D2 receptors in the nucleus accumbens inhibits inflammatory pain. Brain Res 2003; 987(2):135-43.

16. Dolatshahi M, Farbood Y, Sarkaki A, et al. Ellagic acid improves hyperalgesia and cognitive deficiency in 6-hydroxidopamine induced rat model of Parkinson's disease. Iran J Basic Med Sci 2015; 18(1): 38-46.

17. Kambur O, Männistö PT. Catechol-O-methyltransferase and pain. Int Rev Neurobiol 2010; 95:227-79.
18. Jacobsen LM, Eriksen GS, Pedersen LM, et al. Catechol-O-methyltransferase (COMT) inhibition reduces spinal nociceptive activity. Neurosci Lett 2010; 473(3):212-5.

19. Baik JH. Dopamine signalling in reward-related behaviors. Front Neural Circuits 2013; 7:152.

20. Napier TC, Kirby A, Persons AL. The role of dopamine pharmacotherapy and addiction-like behaviors in Parkinson's disease. Prog Neuropsychopharmacol Biol Psychiatry 2020; 102:109942.

21. Potvin S, Grignon S, Marchand S. Human evidence of a supraspinal modulating role of dopamine on pain perception. Synapse 2009; 63(5):390-402.

22. Singh VP, Jain NK, Kulkarni SK. On the antinociceptive effect of fluoxetine, a selective serotonin reuptake inhibitor. Brain Res 2001; 915(2):218-226.

23. Magnusson JE, Fisher K. The involvement of dopamine in nociception: the role of $\mathrm{D}(1)$ and $\mathrm{D}(2)$ receptors in the dorsolateral striatum. Brain Res 2000; 855(2):260-6.

24. Sheng HY, Qu CL, Huo FQ, et al. D2-like but not D1-like dopamine receptors are involved in the ventrolateral orbital cortex-induced antinociception: a GABAergic modulation mechanism. Exp Neurol 2009; 215(1):128-34.

25. Scott DJ, Heitzeg MM, Koeppe RA, et al. Variations in the human pain stress experience mediated by ventral and dorsal basal ganglia dopamine activity. J Neurosci 2006; 26(42):10789-95.

26. Flores JA, El Banoua F, Galán-Rodríguez B, et al. Opiate anti-nociception is attenuated following lesion of large dopamine neurons of the periaqueductal grey: critical role for D1 (not D2) dopamine receptors. Pain 2004; 110(1-2):205-14.

27. Le Bars D, Gozariu M, Cadden SW. Animal models of nociception. Pharmacol Rev 2001; 53(4):597-652.

28. Almanza A, Simón-Arceo K, Coffeen U, et al. A D2-like receptor family agonist produces analgesia in mechanonociception but not in thermonociception at the spinal cord level in rats. Pharmacol Biochem Behav 2015; 137:119-25.

29. Zhu H, Clemens S, Sawchuk M, et al. Expression and distribution of all dopamine receptor subtypes $(\mathrm{D}(1)-\mathrm{D}(5))$ in the mouse lumbar spinal cord: a real-time polymerase chain reaction and non-autoradiographic in situ hybridization study. Neuroscience 2007; 149(4): 885-97.

30. Chakraborty S, Rebecchi M, Kaczocha M, et al. Dopamine modulation of transient receptor potential vanilloid type 1 (TRPV1) receptor in dorsal root ganglia neurons. J Physiol 2016; 594(6):1627-42.

31. Lu Y, Doroshenko M, Lauzadis J, et al. Presynaptic inhibition of primary nociceptive signals to dorsal horn lamina I neurons by dopamine. J Neurosci 2018; 38(41):8809-21.

32. Hache G, Coudore F, Gardier AM, et al. Monoaminergic antidepressants in the relief of pain: potential therapeutic utility of triple reuptake inhibitors (TRIs). Pharmaceuticals (Basel) 2011; 4(2):285-342.

33. Howorth PW, Thornton SR, O'Brien V, et al. Retrograde viral vectormediated inhibition of pontospinal noradrenergic neurons causes hyperalgesia in rats. J Neurosci 2009; 29(41):12855-64.

34. Rommelfanger KS, Weinshenker D. Norepinephrine: the redheaded stepchild of Parkinson's disease. Biochem Pharmacol 2007; 74(2):177-190.

35. Baba H, Goldstein PA, Okamoto M, et al. Norepinephrine facilitates inhibitory transmission in substantia gelatinosa of adult rat spinal cord (part 2): effects on somatodendritic sites of GABAergic neurons. Anesthesiology 2000; 92(2):485-92. 


\title{
Прамипексол и толкапон снижают термическую и механическую ноцицепцию у «наивных» крыс
}

\author{
Анита Михайлова ${ }^{1}$, Илия Костадинов ${ }^{2}$, Нина Дончева $^{1}$, Делян Делев ${ }^{1}$, Христина Златанова \\ ${ }^{1}$ Кафедра фармакологии, токсикологии и фармакотерапии, Факультет фармации, Медицинский университет - Пловдив, Пловдив, Болгария \\ ${ }^{2}$ Кафедра фармакологии и клинической фармакологии, Факультет медицинь, Медицинский университет - Пловдив, Пловдив, Болгария
}

Адрес для корреспонденции: Анита Михайлова, Кафедра фармакологии и лекарственной токсикологии, Факультет фармации, Медицинский университет - Пловдив, бул. „Васил Априлов“ №15A, 4002 Пловдив, Болгария; E-mail: animihailova@gmail.com; Tел.: +359 895 707 148

Дата получения: 5 июня 2020 Дата приемки: 15 июня $2020 \diamond$ Дата публикации: 30 июня 2021

Образец цитирования: Mihaylova A, Kostadinov I, Doncheva N, Delev D, Zlatanova H. Pramipexole and tolcapone alleviate thermal and mechanical nociception in naive rats. Folia Med (Plovdiv) 2021;63(3):377-84. doi: 10.3897/folmed.63.e55136.

\section{Резюме}

Введение: Болезнь Паркинсона (БП) - нейродегенеративное заболевание, характеризующееся в основном двигательными симптомами. В последние десятилетия всё больше внимания уделяется немоторным симптомам, включая боль. Существующие данные свидетельствуют о том, что дофминергическая нейротрансмиссия играет важную роль в контроле боли.

Цель: Целью настоящего исследования было изучить антиноцицептивное действие дофаминергических препаратов прамипексола и толкапона на химические и термические раздражители у „наивных“ крыс.

Материалы и методы: Самцы крыс линии Wistar были разделены на 8 групп (n=8): обработанные физиологическим раствором; диклофенак 25 мг / кг массы тела (м. т.) (положительный контроль); прамипексол 0.5; 1 и 3 мг / кг (м. т.); толкапон 5; 15 и 30 мг / кг (м.т..). Были выполнены испытание на давление лап крысы и подошвенное испытание. Измеряли давление отдёргивания лапы и задержку. Статистический анализ проводился с использованием SPSS 19.

Результаты: В тесте давления на лапы крысы прамипексол в дозах 1 и 3 мг / кг (м. т.) и толкапон в дозах 30 мг / кг (м.т.) Значительно увеличили латентный период через 1, 2 и 3 часа по сравнению с физиологически обработанными группа. раствор $(p<0.05)$. В подошвенном тесте только самая высокая доза прамипексола достигла значимости на третьем часу по сравнению с контролем ( $p<0.05)$. В отличие от прамипексола, три экспериментальные группы, получавшие ТСР (толкапон), значительно увеличили латентное время через 1 и 3 часа по сравнению с группой, получавшей физиологический раствор $(p<0.05)$.

Заключение: Прамипексол и толкапон снижали механическую и термическую ноцицепцию у „наивных“ крыс за счёт увеличения дофаминергической нейротрансмиссии как на спинальном, так и на супраспинальном уровнях. Кроме того, толкапон стимулирует норадренегативное посредничество, что может способствовать его антиноцицептивному эффекту.

\section{Ключевые слова}

дофамин, боль, прамипексол, толкапон 